\title{
Meteorological observations made at Tunbridge Wells, from August 30 to Sept. 17, 1815
}

\section{Thomas Forster}

To cite this article: Thomas Forster (1815) Meteorological observations made at Tunbridge Wells, from August 30 to Sept. 17, 1815, Philosophical Magazine Series 1, 46:209, 238-239, DOI: $10.1080 / 14786441508638530$

To link to this article: http://dx.doi.org/10.1080/14786441508638530

册 Published online: 27 Jul 2009.

Submit your article to this journal $₫$

Џ Article views: 3

Q View related articles $₫$ 
'To James Carpenter, of Wellenhall, in the county of Stafford, currycomb-maker, for his improvement to a curry-comb by inverting the handle over the back of the comb, and thus rendering the pressure when in use more-equal. $-23 \mathrm{~d}$ Aug. -2 months.

\section{LECTURES.}

A Course of Lectures on Chemistry will be conmenced at the Chemical Theatre, 4\%. Great Windmill Street, on Tuesday the $3 \mathrm{~d}$ of Octuber, at Nine in the Morning, by W.T. Brande, F.R.S. L. \& E. Prof. Chem. R. I.,\&c.

The Lectures on Midwifery at the Middlesex Hospital, by Dr. Merriman, Plyysician, Man-Midwife to that Hospital, and Consulting Physician, Man-Midwife to the Westminster General Dispensary, will recommence on Monday, October the 9 th.

School of Medicine in Treland.-The Winter Courses of Lectures on Anatomy, Physiology, Patholoyy, Surgery, Chemistry, Materia Medica, Institutes and Practice of Medicine, will commence on the 6 th of November at their respective hours.

Anatomical Demonstrations will commence the 1st of December.

\section{TO CORRESPONDENTS.}

However just the remarks sent us by "A Sulp-BCiLDrn" may be, they would have the appearance of personality on the part of the Lditor, who never, but by inadvertency, suffers any thing that can be cousidered acrimonious to appear in lis pages, and certainly not without the autbor's real signature. When gentlemen subscribe their names, the Editor considers them the best judges of the language it may be proper for them to employ; but the case is atherwise when the Correspondent is anonymous.

Mr. CarTER's Communication respecting Machinery applicable to SteanBoats should have been sooner noticed. The arrangement which he has proposed is not new; but as it is not generally known, we hoped to have been able, before this time, to have spitred a eorner of one of our plates to illustrate it.

E. S. On Meteoric Stones;-Mr. Spencer On the comparative Specifie Gravity of the Human Budy and Sea Water; - and H. on IIetallic Salts, are deferred for want of room. They shali appear in our next Number.

\section{Meteorological Observations made at Tunbridge Wells, from August 30 to Sept. 17, 1815.}

August 30.-Fair, cumuli, \&c. (at Tunbridge Wells.)

August 31.-Cirrus and cumulostratus; cirri and cirrostrati richly coloured in the evening.

Sept. 1.-Hot bright day, with clear distances, and fine ephemeral cumuli in one plane.

Sept. 2.-Fair day, with much cumulostratıs. Beautiful evening with cirrocumulus, cirrus, \&c.

Sept.3.-Warmer even than yesterday, as is usual after cirrocumulus. Cumuli, cirri, \&c. A breeze with cirrostratus: at night small meteors falling through clear sky into cirrostratus. 
Sept. 4.-Clouded early, then clear with cumuli below cirri, and windy from WSW.

Sept.5.-Fair day, somewhat cooler, and various clouds. Calm evening, and very fine indeed : features of the different modifications not strongly marked. The sky exhibited in places a fire.

Sept. 6.-Cooler air still. Clear morning with faint features of cirrostratus; cumuli in the day. The white and partial strati which I saw creeping up the valley at sunrise, as 1 rode to Berwash, gave place afterwards to greater mist, which made the horizon obseure. Fine evening, and some red in the sunset.

Sepl. 7.-Fine day; cumuli prevail. N. wind. A fair, still evening, with cirri, and a fine deep red refraction at sunset and for some time alterwards.

Scpt.8.- Fine morning when stratus cleared off. Clear sunset and red-coloured horizon. At night small meteors.

Sept.9.-Fair dry day, with northerly wind, and some cumuli. In the evening, features of the other modifications. At sunset, a fine red blush marked by diverging red and blue bars.

Sept. 10. - Fair and almost cloudless, save a few cumuli. Fine clear sunset; the horizon about the west a beautiful red, fading into yellow afterwards.

Sept. 11.-Fair but misty horizon, as of late ; in the morning cirrocumulus appeared early. I saw features of cirrostratus in lafge bars below it: cumulostratus and indication of thunder, with increased warnth. It cleared off, and we had a fine calm evening, with mixed and coloured clouds.

Sept. 12.- Warm clear day, with cir rocumulus, \&zc; red sunset.

Scpt. 13,- Fine clear dry day again, and quite without a cloud all day. The heat increased, but there were light gales from SE.

Sept. 14.-Fine elear hot day with few clouds, and a beautifnl sunset; some fleecy cumuli by moonlight.

Sept. 15.- - Very hot dày and clear, except a few cirri, \&c. and some small cumuli; dry $\mathrm{SE}$ wind.

Sept. 16.- Hot morning with a light shower early; throngh the day cumulostrains, \&c. increased, and we had. gentle showers at night.

Sept. 17.-Hot fair morning, cirri and cumuli ill-defined.

Thomas Forster. 